\title{
Hydration and Dispersion Forces in Hydroxypropylcellulose Phase Behavior Supporting Information
}

\author{
Guy W. Dayhoff II and David M. Rogers \\ Department of Chemistry, University of South Florida \\ davidrogers@usf.edu
}

April 11, 2019

Electronic address: davidrogers@usf .edu

Fig. S1 shows the XY-area equilibration in the constant pressure series of simulations; the plot suggests $\approx 200 \mathrm{~ns}$ of simulation time is necessary for the unit cell's xy-area to reach a steady state at a constant temperature of $300 \mathrm{~K}$. For our simulations, we ran for more than three times the apparent equilibration time. The GROMOS model displays an initial relaxation rate about twice that of the OPLS model.

Fig. S2 shows the pressure equilibration in the constant area series of Drude simulations at $283.15 \mathrm{~K}$.

Fig. S3 shows the total simulation cell volume as a function of the number of waters present over all simulations with a given forcefield (points). The slope and intercept of the straight-line fit give the bulk water density and excluded volume of all nine HPC polymers present. The resulting excluded volume per monomer is given in Table 1 of the main text. GROMOS predicts the largest excluded volume, OPLS and CHARMM are in general agreement and Drude predicts the smallest.

Fig. S4 plots the polymer volume fraction in the mixed phase, $1-\rho_{m} / \rho_{b}$ against the 2D HPC surface coverage, $\sigma=9 / A$. This should be a straight line with zero intercept and slope equal to $A_{0}$, the excluded area per polymer. The number density of water in the mixed phase, $\rho_{m}=N_{m} /\left(L_{m} A\right)$, was computed over a height range $\left(L_{m}\right)$ where $\rho_{m}(z)$ was approximately constant. Fit results are also given in Table 1 .

Fig. S5 shows the overall scheme employed for parameterizing the OPLS and Drude forcefields for betacellulose. We use equivalence to fill in the missing parameters required for simulating beta-cellulose, i.e. two bond types, seven angle types, and sixteen dihedrals.

Fig. S6 shows the overall scheme employed for param-

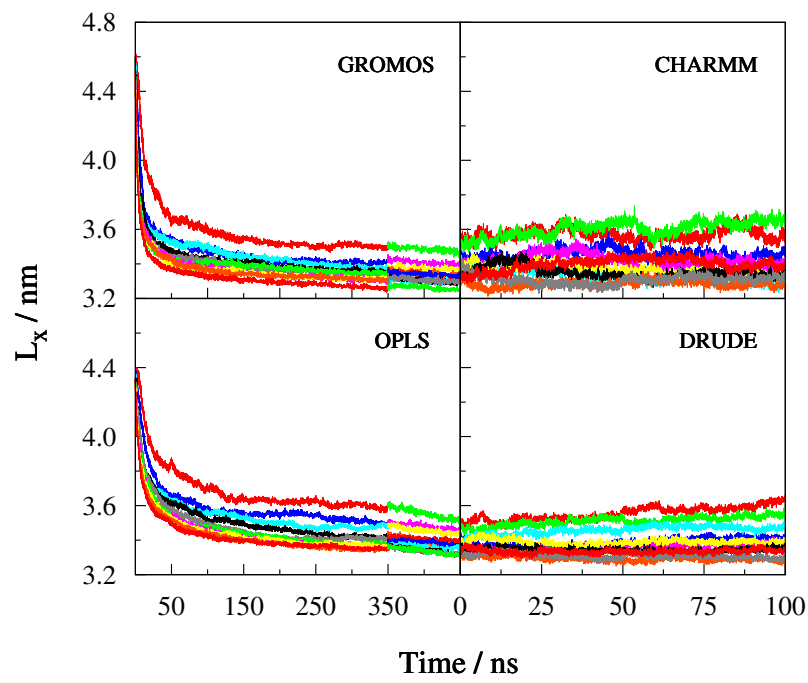

Figure S1: Constant pressure series equilibration for hot $(318.15 \mathrm{~K})$ variant. We run GROMOS and OPLS models for $350 \mathrm{~ns}$ at constant pressure (see Table 2) and constant temperature $(300 \mathrm{~K})$. Then we set temperature to $318.15 \mathrm{~K}$ and run for 100 ns. Finally, we use the final frame of the OPLS runs as starting points for CHARMM and Drude models, which we run for 100ns.

eterizing the GROMOS, OPLS, CHARMM, and Drude forcefields for hydroxypropylcellulose. We used equivalence to fill in missing parameters needed for simulating HPC. One new bond type, twelve new angle types, and twenty new dihedrals were required in total. 


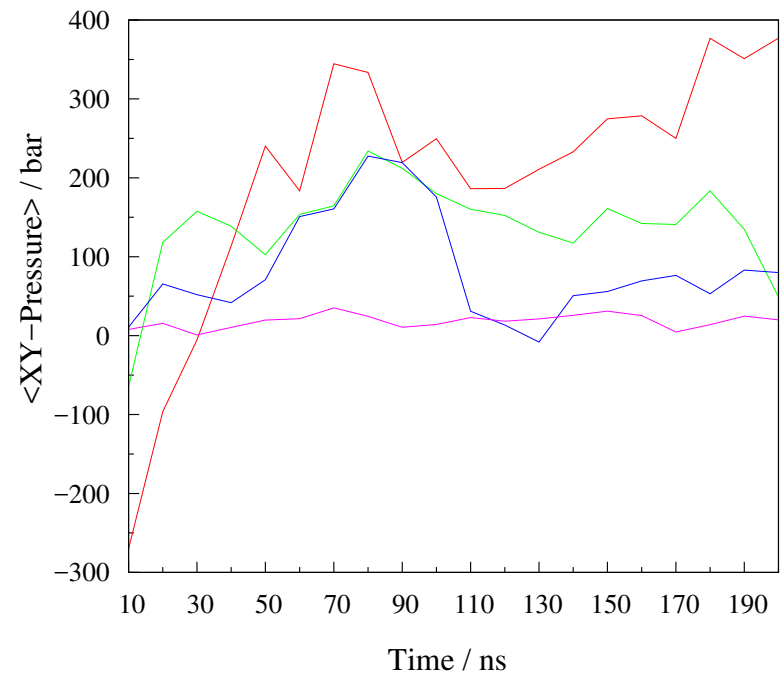

Figure S2: Pressure equilibration as a function of time in the constant area $283.15 \mathrm{~K}$ Drude simulations. The pressure is reported as the block average pressure over 10ns intervals.

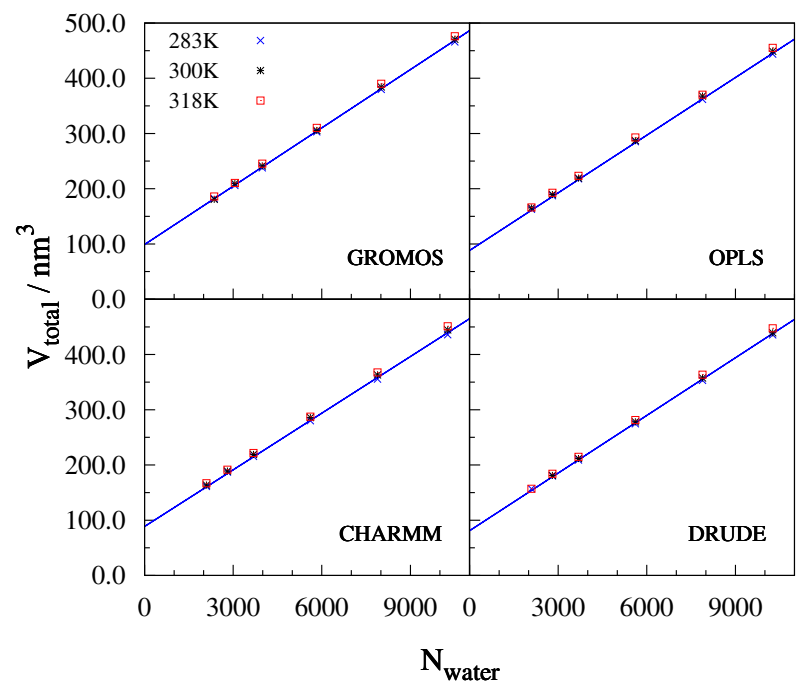

Figure S3: Volume vs. Water Count in the GROMOS, OPLS, CHARMM, and Drude systems. Simulation derived data is plotted as points corresponding to the temperature they were evolved in. A straight line is fit to the data in order to extrapolate to the zero water case.

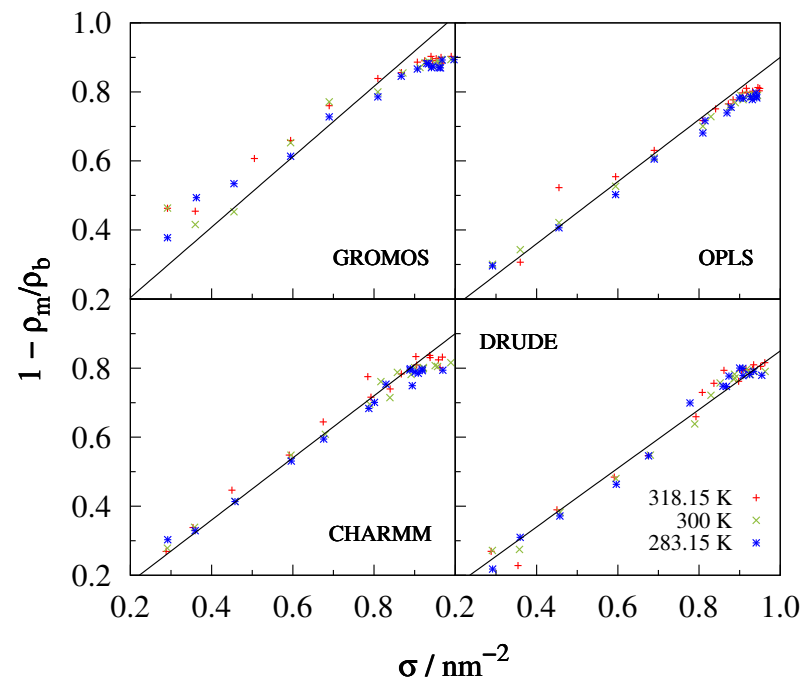

Figure S4: Mixed Phase Water Density vs. XY-Area in the GROMOS, OPLS, CHARMM, and Drude systems. Simulation derived data is plotted as points corresponding to the temperature they were evolved in. A straight line is fit to the data in order to extrapolate to the zero water density case. 


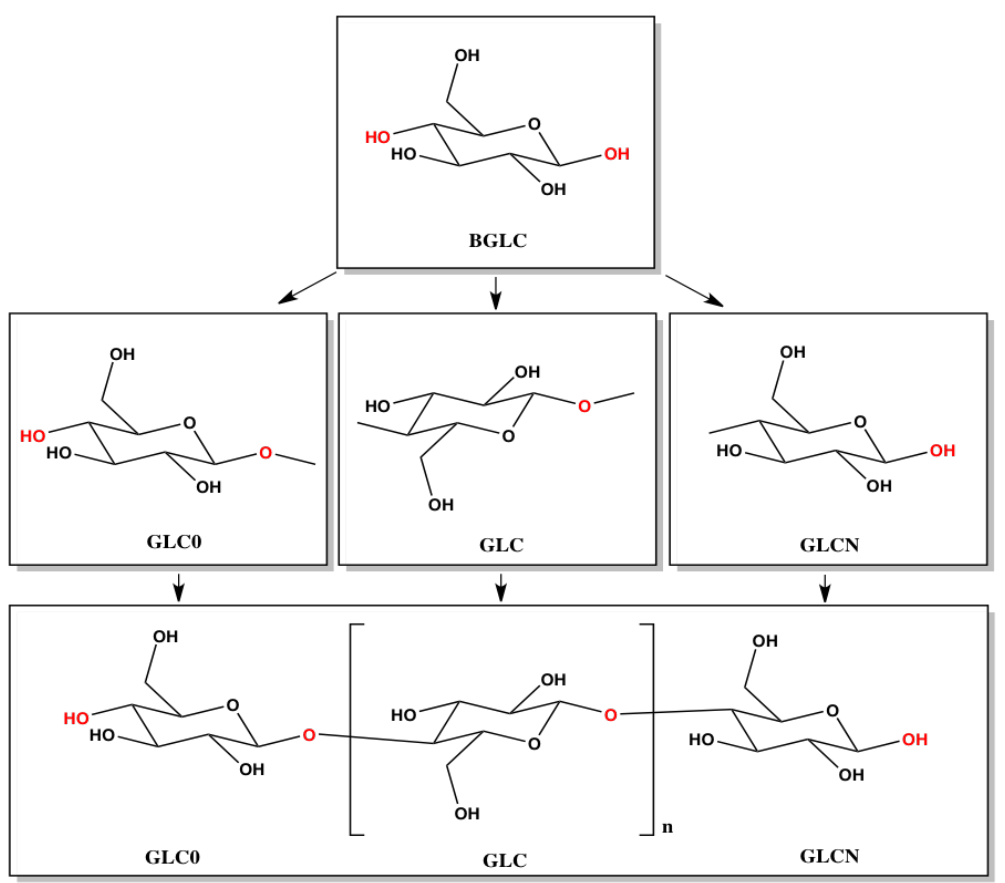

Beta 1-4 Cellulose

\begin{tabular}{l}
\hline New Bond Types \\
\hline$C_{4}-+O_{1}$ \\
$C_{1}-O_{1}$
\end{tabular}

\begin{tabular}{c}
$\mathrm{O}_{5}-\mathrm{C}_{1}-\mathrm{O}_{1}$ \\
$\mathrm{C}_{3}-\mathrm{C}_{4}-+\mathrm{O}_{1}$ \\
$\mathrm{C}_{2}-\mathrm{C}_{4}-+\mathrm{O}_{1}$ \\
$\mathrm{H}_{4}-\mathrm{C}_{4}-+\mathrm{O}_{1}$ \\
$+\mathrm{C}_{1}-+\mathrm{O}_{1}-\mathrm{C}_{4}$ \\
\hline
\end{tabular}

\begin{tabular}{c}
\hline New Angle Types \\
\hline $\mathrm{H}_{1}-\mathrm{C}_{1}-\mathrm{O}_{1}$ \\
$\mathrm{C}_{2}-\mathrm{C}_{1}-\mathrm{O}_{1}$ \\
$\mathrm{O}_{5}-\mathrm{C}_{1}-\mathrm{O}_{1}$ \\
$\mathrm{C}_{3}-\mathrm{C}_{4}-+\mathrm{O}_{1}$ \\
$\mathrm{C}_{2}-\mathrm{C}_{4}-+\mathrm{O}_{1}$ \\
$\mathrm{H}_{4}-\mathrm{C}_{4}-+\mathrm{O}_{1}$ \\
$+\mathrm{C}_{1}-+\mathrm{O}_{1}-\mathrm{C}_{4}$ \\
\hline
\end{tabular}

\begin{tabular}{ll}
\hline New Dihedral Types & \\
\hline $\mathrm{C}_{2}-\mathrm{C}_{3}-\mathrm{C}_{4}-+\mathrm{O}_{1}$ & $\mathrm{O}_{1}-\mathrm{C}_{1}-\mathrm{C}_{2}-\mathrm{C}_{3}$ \\
$\mathrm{O}_{5}-\mathrm{C}_{5}-\mathrm{C}_{4}-+\mathrm{O}_{1}$ & $\mathrm{O}_{1}-\mathrm{C}_{1}-\mathrm{O}_{5}-\mathrm{C}_{5}$ \\
$\mathrm{H}_{5}-\mathrm{C}_{5}-\mathrm{C}_{4}-+\mathrm{O}_{1}$ & $+\mathrm{C}_{1}-+\mathrm{O}_{1}-\mathrm{C}_{4}-\mathrm{C}_{5}$ \\
$\mathrm{C}_{6}-\mathrm{C}_{5}-\mathrm{C}_{4}-+\mathrm{O}_{1}$ & $+\mathrm{C}_{1}-+\mathrm{O}_{1}-\mathrm{C}_{4}-\mathrm{C}_{3}$ \\
$\mathrm{H}_{3}-\mathrm{C}_{3}-\mathrm{C}_{4}-+\mathrm{O}_{1}$ & $+\mathrm{C}_{1}-+\mathrm{O}_{1}-\mathrm{C}_{4}-\mathrm{H}_{4}$ \\
$\mathrm{O}_{3}-\mathrm{C}_{3}-\mathrm{C}_{4}-+\mathrm{O}_{1}$ & $\mathrm{C}_{4}-+\mathrm{O}_{1}-+\mathrm{C}_{1}-+\mathrm{C}_{2}$ \\
$\mathrm{O}_{1}-\mathrm{C}_{1}-\mathrm{C}_{2}-\mathrm{H}_{2}$ & $\mathrm{C}_{4}-+\mathrm{O}_{1}-+\mathrm{C}_{1}-+\mathrm{O}_{5}$ \\
\hline $\mathrm{O}_{1}-\mathrm{C}_{1}-\mathrm{C}_{2}-\mathrm{O}_{2}$ & $\mathrm{C}_{4}-+\mathrm{O}_{1}-+\mathrm{C}_{1}-+\mathrm{H}_{1}$ \\
\hline
\end{tabular}

\section{New Dihedral Types}

$$
\mathrm{O}_{5}-\mathrm{C}_{5}-\mathrm{C}_{4}-+\mathrm{O}_{1} \quad \mathrm{O}_{1}-\mathrm{C}_{1}-\mathrm{O}_{5}-\mathrm{C}_{5}
$$$$
\mathrm{H}_{5}-\mathrm{C}_{5}-\mathrm{C}_{4}-+\mathrm{O}_{1} \quad+\mathrm{C}_{1}-+\mathrm{O}_{1}-\mathrm{C}_{4}-\mathrm{C}_{5}
$$$$
\mathrm{C}_{6}-\mathrm{C}_{5}-\mathrm{C}_{4}-+\mathrm{O}_{1} \quad+\mathrm{C}_{1}-+\mathrm{O}_{1}-\mathrm{C}_{4}-\mathrm{C}_{3}
$$$$
\mathrm{H}_{3}-\mathrm{C}_{3}-\mathrm{C}_{4}-+\mathrm{O}_{1} \quad+\mathrm{C}_{1}-+\mathrm{O}_{1}-\mathrm{C}_{4}-\mathrm{H}_{4}
$$$$
\mathrm{O}_{3}-\mathrm{C}_{3}-\mathrm{C}_{4}-+\mathrm{O}_{1} \quad \mathrm{C}_{4}-+\mathrm{O}_{1}-+\mathrm{C}_{1}-+\mathrm{C}_{2}
$$$$
\mathrm{O}_{1}-\mathrm{C}_{1}-\mathrm{C}_{2}-\mathrm{O}_{2} \quad \mathrm{C}_{4}-+\mathrm{O}_{1}-+\mathrm{C}_{1}-+\mathrm{H}_{1}
$$

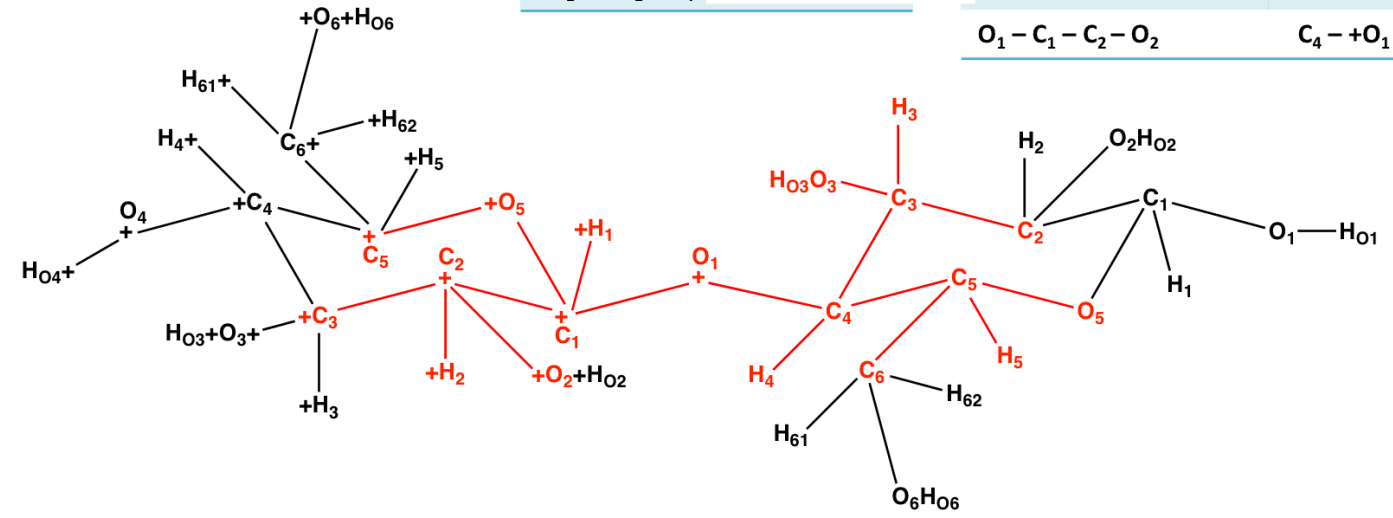

Figure S5: Overview of the parameterization scheme to enable simulations of cellulose in the OPLS and Drude forcefields we employed. (Scheme) Using the existing glucose residues in each forcefield, we constructed three new residues to model betacellulose polymers. (Tables) Parameters which were not present in the forcefields prior to this work which were required to enable simulations of beta-cellulose. Since glucose was already parameterized, these parameters correspond primarily to the glycosidic linkage between monomeric units. (Structure) The structure of cellobiose with the region in red highlighting the atoms involved in the new parameters presented in the tables. 


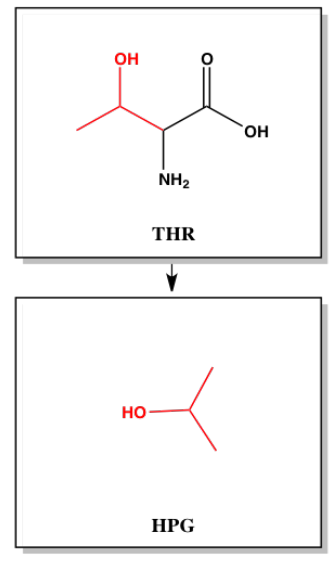

Hydroxypropyl Group

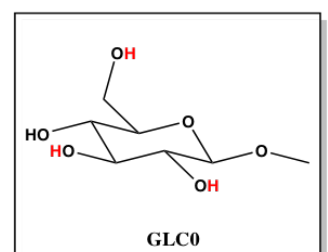

$\downarrow$

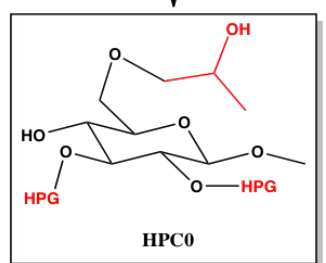

$\downarrow$

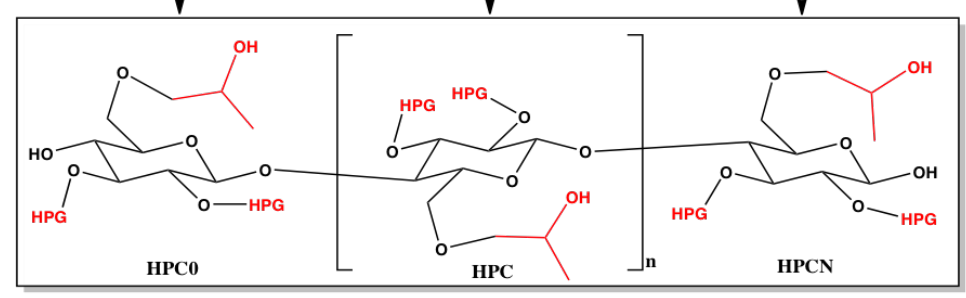

Beta 1-4 Hydroxypropylcellulose

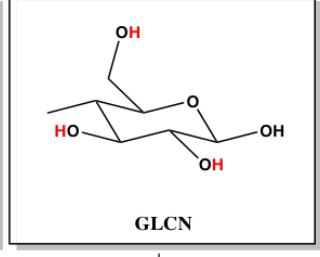

$\downarrow$

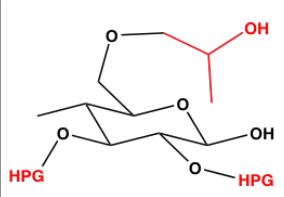

HPCN

.

\begin{tabular}{l}
\hline New Bond Types \\
\hline$O^{*}-C_{A}$ \\
\hline New Angle Types \\
\hline$C_{1}-C_{2}-O_{2}$ \\
$H_{5}-C_{5}-C_{6}$ \\
$O_{5}-C_{5}-C_{6}$ \\
$C_{4}-C_{5}-C_{6}$ \\
$C_{A}-O_{2}-C_{2}$ \\
$C_{5}-C_{6}-H_{6}$ \\
$C_{5}-C_{6}-O_{6}$ \\
$O_{B}-C_{B}-C_{A}$ \\
$C_{A}-C_{B}-C_{6}$ \\
$C_{A}-C_{B}-H_{B}$ \\
$C_{B}-C_{A}-H_{A}$ \\
$O_{*}-C_{A}-C_{B}$ \\
\hline
\end{tabular}

\begin{tabular}{ll}
\hline New Dihedral Types \\
\hline $\mathrm{O}_{2}-\mathrm{C}_{2}-\mathrm{C}_{4}-\mathrm{O}_{3}$ & $\mathrm{C}_{4}-\mathrm{C}_{5}-\mathrm{C}_{6}-\mathrm{O}_{6}$ \\
$\mathrm{C}_{1}-\mathrm{C}_{2}-\mathrm{O}_{2}-\mathrm{C}_{\mathrm{A}}$ & $\mathrm{H}_{5}-\mathrm{C}_{5}-\mathrm{C}_{6}-\mathrm{O}_{6}$ \\
$\mathrm{C}_{2}-\mathrm{C}_{3}-\mathrm{O}_{3}-\mathrm{C}_{\mathrm{A}}$ & $\mathrm{C}_{1}-\mathrm{C}_{2}-\mathrm{C}_{3}-\mathrm{O}_{3}$ \\
$\mathrm{H}_{2}-\mathrm{C}_{2}-\mathrm{O}_{2}-\mathrm{C}_{\mathrm{A}}$ & $\mathrm{C}_{2}-\mathrm{O}_{2}-\mathrm{C}_{\mathrm{A}}-\mathrm{C}_{\mathrm{B}}$ \\
$\mathrm{C}_{2}-\mathrm{O}_{2}-\mathrm{C}_{\mathrm{A}}-\mathrm{H}_{\mathrm{A}}$ & $\mathrm{C}_{6}-\mathrm{O}_{6}-\mathrm{C}_{\mathrm{A}}-\mathrm{C}_{\mathrm{B}}$ \\
$\mathrm{O}_{2}-\mathrm{C}_{2}-\mathrm{C}_{1}-\mathrm{H}_{1}$ & $\mathrm{C}_{5}-\mathrm{C}_{4}-\mathrm{C}_{3}-\mathrm{O}_{3}$ \\
$\mathrm{O}_{1}-\mathrm{C}_{1}-\mathrm{C}_{2}-\mathrm{O}_{2}$ & $\mathrm{O}_{*}-\mathrm{C}_{\mathrm{A}}-\mathrm{C}_{\mathrm{B}}-\mathrm{H}_{\mathrm{B}}$ \\
\hline $\mathrm{O}_{2}-\mathrm{C}_{2}-\mathrm{C}_{1}-\mathrm{O}_{5}$ & $\mathrm{C}_{\mathrm{A}}-\mathrm{O}_{6}-\mathrm{C}_{6}-\mathrm{C}_{5}$ \\
$\mathrm{O}_{5}-\mathrm{C}_{5}-\mathrm{C}_{6}-\mathrm{O}_{6}$ & $\mathrm{O}_{*}-\mathrm{C}_{\mathrm{A}}-\mathrm{C}_{B}-\mathrm{C}_{G}$ \\
$\mathrm{O}_{1}-\mathrm{C}_{1}-\mathrm{C}_{2}-\mathrm{O}_{2}$ & $\mathrm{O}_{*}-\mathrm{C}_{\mathrm{A}}-\mathrm{C}_{\mathrm{B}}-\mathrm{O}_{\mathrm{B}}$ \\
\hline
\end{tabular}

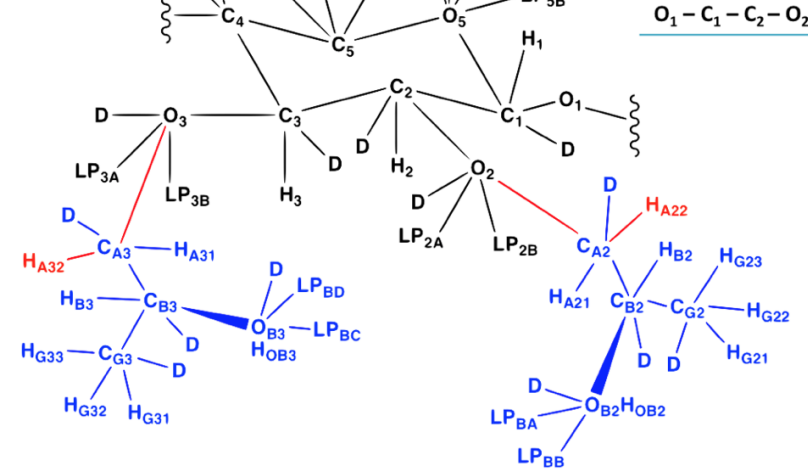

Figure S6: Overview of the parameterization scheme to enable simulations of HPC in the GROMOS, OPLS, CHARMM, and Drude forcefields. (Scheme) Building off of either the existing cellulose residues (GROMOS \& CHARMM) or our newly created cellulose residues (OPLS \& Drude), we construct three new residues to allow simulations of HPC. We excise a portion of threonine to obtain the hydroxypropyl group (HPG) which replaces the 2, 3, and 6-hydroxyl groups of beta-cellulose. (Tables) Parameters that were not previously available in the forcefields prior to this work which were necessary to enable simulations of HPC. (Structure) The structure of an internal HPC monomer; the transplanted HPG from threonine is highlighted in blue, the additional bonds and hydrogens needed to complete the structure are in red. 